Revista de la red interuniversitaria de estudios sobre las literaturas rioplatenses contemporáneas en Francia

$18 \mid 2018$

El río y la ciudad

\title{
Let the river run
}

\section{Daniel Link}

\section{OpenEdition}

Journals

\section{Edición electrónica}

URL: http://journals.openedition.org/lirico/5309

DOI: 10.4000/lirico.5309

ISSN: 2262-8339

Editor

Réseau interuniversitaire d'étude des littératures contemporaines du Río de la Plata

\section{Referencia electrónica}

Daniel Link, «Let the river run », Cuadernos LIRICO [En línea], 18 | 2018, Puesto en línea el 05 octubre 2018, consultado el 11 mayo 2019. URL : http://journals.openedition.org/lirico/5309 ; DOI : 10.4000/ lirico.5309

Este documento fue generado automáticamente el 11 mayo 2019.

\section{(c) (i) (9)}

Cuadernos LIRICO está distribuido bajo una Licencia Creative Commons Atribución-NoComercialSinDerivar 4.0 Internacional. 


\section{Let the river run}

\section{Daniel Link}

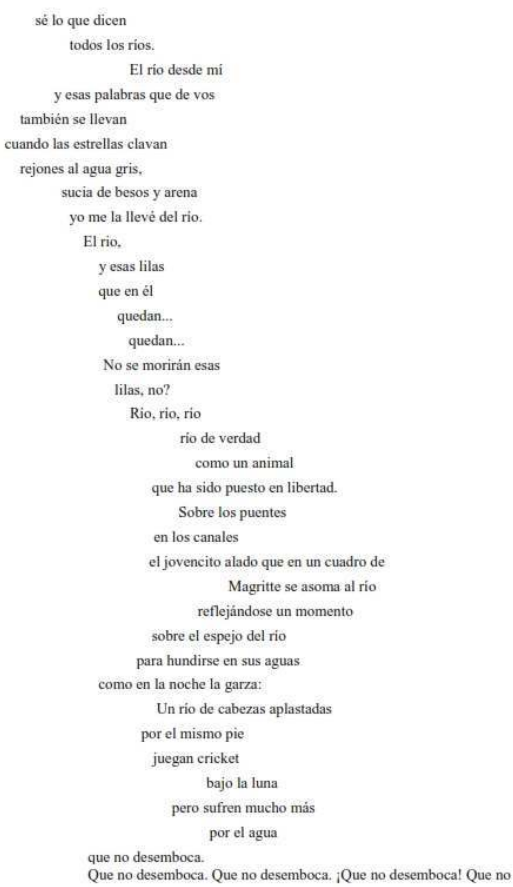

